\title{
Review of the geographic distribution of Micrurus decoratus (Jan, 1858) (Serpentes: Elapidae)
}

\author{
Rodrigo Castellari Gonzalez', Thiago Silva-Soares', Thiago Marcial de Castro², and Renato \\ Silveira Bérnils ${ }^{3}$ \\ ${ }^{1}$ Universidade Federal do Rio de Janeiro, Museu Nacional, Departamento de Vertebrados, Setor de Herpetologia, Quinta da \\ Boa Vista, São Cristóvão, 20940-040, Rio de Janeiro, RJ, Brazil. \\ E-mails: rodcastgon@gmail.com, thiagosilvasoares@hotmail.com. \\ ${ }^{2}$ Centro Universitário São Camilo, Rua São Camilo de Lellis, 1, Paraíso, 29304-910, Cachoeiro de Itapemirim, ES, Brazil. \\ E-mail: thiagomarcial@yahoo.com.br. \\ ${ }^{3}$ Universidade Federal do Espírito Santo, Centro Universitário Norte do Espírito Santo, Departamento de Ciências Agrárias e \\ Biológicas, 29932-540, São Mateus, ES, Brazil. E-mail: renatobernils@gmail.com.
}

\begin{abstract}
Review of the geographic distribution of Micrurus decoratus (Jan, 1858) (Serpentes: Elapidae). Micrurus decoratus (Jan, 1858) is a poorly known species of coral snake, with a controversial history concerning its geographical range. The lack of consensus among researchers, since its original description, is largely due to the reporting of erroneous localities in publications. Herein we present the geographical range for the species based on the review of 184 records from 67 different municipalities in Brazil, including two new records for the state of Espírito Santo, extending its distribution to ca. $300 \mathrm{~km}$ northward from the previous northernmost locality. We also comment on doubtful records for the states of Rio Grande do Sul and Bahia, which contain no accurate data. We restrict the occurrence of Micrurus decoratus to the Atlantic Rainforest, with elevation range from 400 up to 1,600 m in the Brazilian states of Santa Catarina, Paraná, São Paulo, Rio de Janeiro, Minas Gerais and Espírito Santo.
\end{abstract}

Keywords: Altitude rainforest endemism, coral snake, doubtful records, new records, geographical range. 


\begin{abstract}
Resumo
Revisão da distribuição geográfica de Micrurus decoratus (Jan, 1858) (Serpentes: Elapidae). Micrurus decoratus (Jan, 1858) é uma espécie pouco conhecida de cobra-coral, com uma história controversa sobre a sua distribuição geográfica. A falta de consenso entre os pesquisadores, desde a sua descrição original, deve-se em grande parte a registros de localidades errôneas em publicações. Aqui apresentamos a distribuição geográfica da espécie com base na revisão de 184 registros de 67 municípios brasileiros, incluindo dois novos registros para o estado do Espírito Santo, estendendo sua distribuição em cerca de $300 \mathrm{~km}$ em direção ao norte da localidade mais setentrional anterior. Apresentamos também comentários sobre os registros duvidosos para os estados do Rio Grande do Sul e Bahia, que não apresentam dados precisos. Aqui restringimos a ocorrência de Micrurus decoratus à Mata Atlântica, com altitudes entre 400 e 1600 m, nos estados brasileiros de Santa Catarina, Paraná, São Paulo, Rio de Janeiro, Minas Gerais e Espírito Santo. Assim, esperamos contribuir para melhor compreender a distribuição real dessa cobra-coral.
\end{abstract}

Palavras-chave: amplitude de distribuição geográfica, cobra-coral, endemismo de floresta de altitude, registros duvidosos e novos.

\section{Introduction}

The genus Micrurus Wagler, 1824 currently contains about 70 species worldwide (30 species in Brazil), all of which are coral snakes (Campbell and Lamar 2004, Bérnils and Costa 2013). Although the genus is widely distributed in America, many aspects of coral snakes' biology are still unknown. This is due to their secretive habits, which includes inhabiting underground galleries and leaf-litter. They are difficult to find in nature and, consequently, they are poorly represented in herpetological collections (Campbell and Lamar 1989, 2004, Marques 2002, Terribile et al. 2007).

Micrurus decoratus (Jan, 1858) is one of the most poorly known coral snakes. It is characterized by having black rings organized into 13-19 body triads; tail with $1-12 / 3$ triads; the black rings are shorter than the red ones and the first triad (neck) is incomplete (Figures 2 and 3 ); temporals $0+1$; ventrals 209-218 in females and 195-208 in males; subcaudals 16-19 in females and 19-22 in males. The color pattern and the temporal formula easily distinguish $M$. decoratus from all other Micrurus (Schmidt 1936, Roze 1996, Campbell and Lamar 1989, 2004).
The geographic distribution of $M$. decoratus has been controversial since its original description, with no consensus amongst today's researchers achieved thus far. Jan (1858) described the species Elaps decoratus based on a specimen from "Mexico", but this locality was considered "in error" by subsequent authors (Ihering 1910, Peters and Orejas-Miranda 1970, Campbell and Lamar 1989, 2004, Roze 1996).

Several studies have discussed the distribution of this species, most of which were reviewed by Campbell and Lamar (1989, 2004), Marques (2002), and Terribile et al. (2007). The amassed data from all previous studies brought to light the distributional pattern of Micrurus decoratus, which was known to be restricted to the southeastern and southern Brazilian Atlantic Rainforest in the states of Minas Gerais, Rio de Janeiro, São Paulo, and Paraná (Campbell and Lamar 1989, 2004, Marques 2002, Terribile et al. 2007, Hartmann et al. 2009).

The state of Espírito Santo in southeastern Brazil remains an under-sampled region for snakes. Indeed, only a few studies of species richness of this state have thus far been produced (e.g., Rocha 1998, Tonini et al. 2010, SilvaSoares et al. 2011, Ferreira and Silva-Soares 2012). None of these aforementioned studies 
mention the occurrence of Micrurus decoratus in the state.

Here we present a new distribution map of Micrurus decoratus, a revision of literature and collection records, two new records for the state of Espírito Santo, southeastern Brazil, and comments on two doubtful records: one for Rio Grande do Sul and other for Bahia, Brazil.

\section{Materials and Methods}

Records of Micrurus decoratus were obtained from the following Brazilian collections (acronyms are according to Sabaj-Pérez 2013): Coleção Herpetológica Alphonse Richard Hoge, Instituto Butantan, São Paulo (IBSP); Museu de Ciências Naturais, Fundação Zoobotânica, Rio Grande do Sul (MCN); Museu de Biologia Professor Mello Leitão, Espírito Santo (MBML); Museu de História Natural Capão da Imbuia, Paraná (MHNCI); Museu Nacional do Rio de Janeiro, Rio de Janeiro (MNRJ); Museu de Zoologia da Universidade de São Paulo, São Paulo (MZUSP); Naturhistorisches Museum, Vienna, Austria (NHMW); Universidade Federal de Juiz de Fora, Minas Gerais (UFJF); Museu de Zoologia da Universidade Estadual de Campinas “Adão José Cardoso", São Paulo (ZUEC); and Universidade Federal do Rio de Janeiro, Rio de Janeiro (ZUFRJ). Additional data were obtained from literature (Ihering 1910, Amaral 1921, Lutz and Mello 1923, Amaral 1977, Scrocchi 1992, Silva-Jr and Sites 2001, Campbell and Lamar 2004, Marques et al. 2001, 2004, Terribile et al. 2007, Hartmann et al. 2009).

Specimens were examined under a stereomicroscope. Terminology for scale counting, color pattern and taxonomy follows Roze (1996) and Campbell and Lamar (2004). Sex was verified through an incision in the first subcaudal scales. Measurements for snout-vent (SVL) and tail length (TL) were taken with a metallic ruler to the nearest $1 \mathrm{~mm}$. SVL was measured from the tip of the rostral scale to the posterior region of the anal plate, and TL from the anterior edge of first subcaudal to the end of the terminal spine.
Railway stations in operation on or off, with their former or current names were obtained online (Giesbrecht 2014) and also by consulting the maps from IBGE at scales of 1:50,000, 1:100,000, 1: 250,000 (IBGE 2014).

Altitude data were taken directly from the toponym names in Google Earth (7.1.1.1888) (Google 2013), with rounded values in tens (i.e., from 10 to $10 \mathrm{~m}$ ), unless when the altitude where the collector obtained the specimen was clearly indicated in the record books. Specimens without precise data of origin, for which we had only the name of the municipality in which it was collected, the altitude was taken at the central area of the municipal seat. After this, the geographic database was transported into the Diva GIS version 7.5.0.0 program (Hijmans 2012), where the map was generated.

\section{Results}

We obtained 184 records of Micrurus decoratus from 67 different municipalities (Appendix I) in the Brazilian states of Santa Catarina (one municipality), Paraná (3), São Paulo (45), Rio de Janeiro (8), Minas Gerais (8) and Espírito Santo (2) (Figure 1). Two doubtful records were found: one for the state of Rio Grande do Sul and another for the state of Bahia. Both doubtful records are not considered in the map.

The southernmost record was at Joinville, Santa Catarina $\left(26^{\circ} 18^{\prime} 15^{\prime \prime} \mathrm{S}\right)$, whereas the northernmost record was at Venda Nova do Imigrante, Espírito Santo (20²6'24" S) (new record). The record of Joinville is located at sea level due to the lack of precise toponym, so the altitude was taken at the central area of the municipal seat. For the other records, the altitudinal range for this species ranged from 400 $\mathrm{m}$ a.s.l. (Resende, Rio de Janeiro) up to 1,600 m a.s.l., at Ibitipoca State Park, Lima Duarte, Minas Gerais (mode $=750 \mathrm{~m}, N=9$; mean $=814.6 \mathrm{~m}$ ).

The new records presented here are: MBML 2010 (Figure 2A), collected in 20 September 2004 by TMC, at Serra da Maravilha, in the 


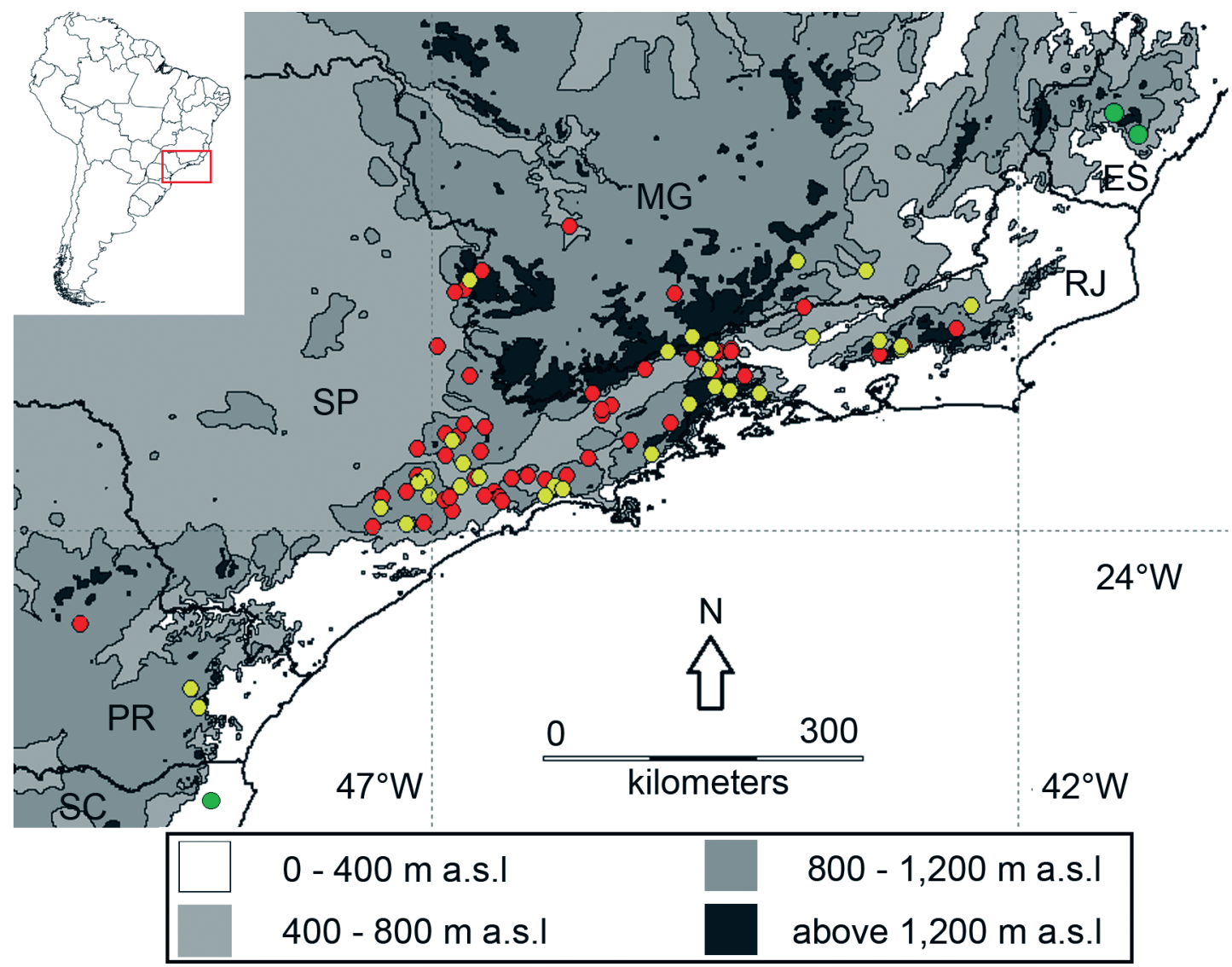

Figure 1. Records of Micrurus decoratus found in the present study. Red dots: records with low accuracy (i.e., specimens which have information only on the municipality or the railway station from which they were sent to collections); yellow dots: accurate records; green dots: reliable extremes of the species range: two new records for Espírito Santo (ES), voucher confirmation to Santa Catarina (SC). Abbreviations: ES = Espírito Santo; MG = Minas Gerais; PR = Paraná; RJ = Rio de Janeiro; SC = Santa Catarina; $\mathrm{SP}=$ São Paulo.

municipality of Alfredo Chaves, state of Espírito Santo (20'32'12" S, 4048'48" W; $1000 \mathrm{~m}$ a.s.l.) (GPS Garmin; Model: eTrex Vista HCx); male, $\mathrm{SVL}=416 \mathrm{~mm} ; \mathrm{TL}=28 \mathrm{~mm} ; 13$ complete triads on the body; tail with $1+1 / 2$ triad; dorsals $15 / 15 / 15$; supralabials $7 / 7$; infralabials $6 / 6$; oculars $1+2 / 1+2$; temporals $0+1 / 0+1$; ventrals 186; divided cloacal plate, and subcaudals $17 / 17$ (incomplete tail).
The second specimen was collected by TMC, MNRJ 22742 (Figures 2B and 3), at Fazenda Brunoro, in the municipality of Venda Nova do Imigrante, in the state of Espírito Santo (2026'24" S, 41 ${ }^{\circ} 10^{\prime} 54^{\prime \prime} \mathrm{W}$; $750 \mathrm{~m}$ a.s.l.) (GPS Garmin; Model: eTrex Vista HCx), in September 2009; male, SVL = $178 \mathrm{~mm}$; TL = $24 \mathrm{~mm}$; 9+1/2 triads on the body; tail with $1+1 / 2$ triad; dorsals $15 / 15 / 15$; supralabials $7 / 7$; infralabials $7 / 7$; 

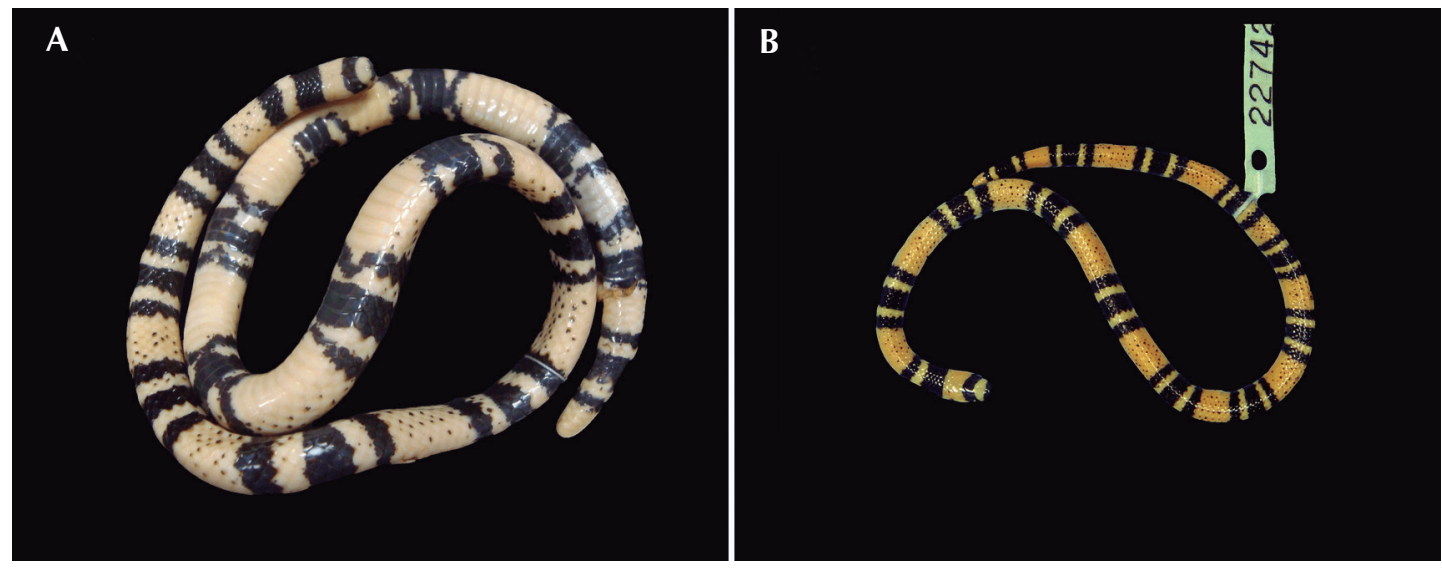

Figure 2. First records of Micrurus decoratus in Espírito Santo state. Preserved specimens from the new localities: (A) MBML 2010 (Male, SVL = 416 mm, TL = 28 mm, Alfredo Chaves, Espírito Santo state); (B) MNRJ 22742 (Male, SVL $=178 \mathrm{~mm}, \mathrm{TL}=24 \mathrm{~mm}$, Venda Nova do Imigrante, Espírito Santo state).

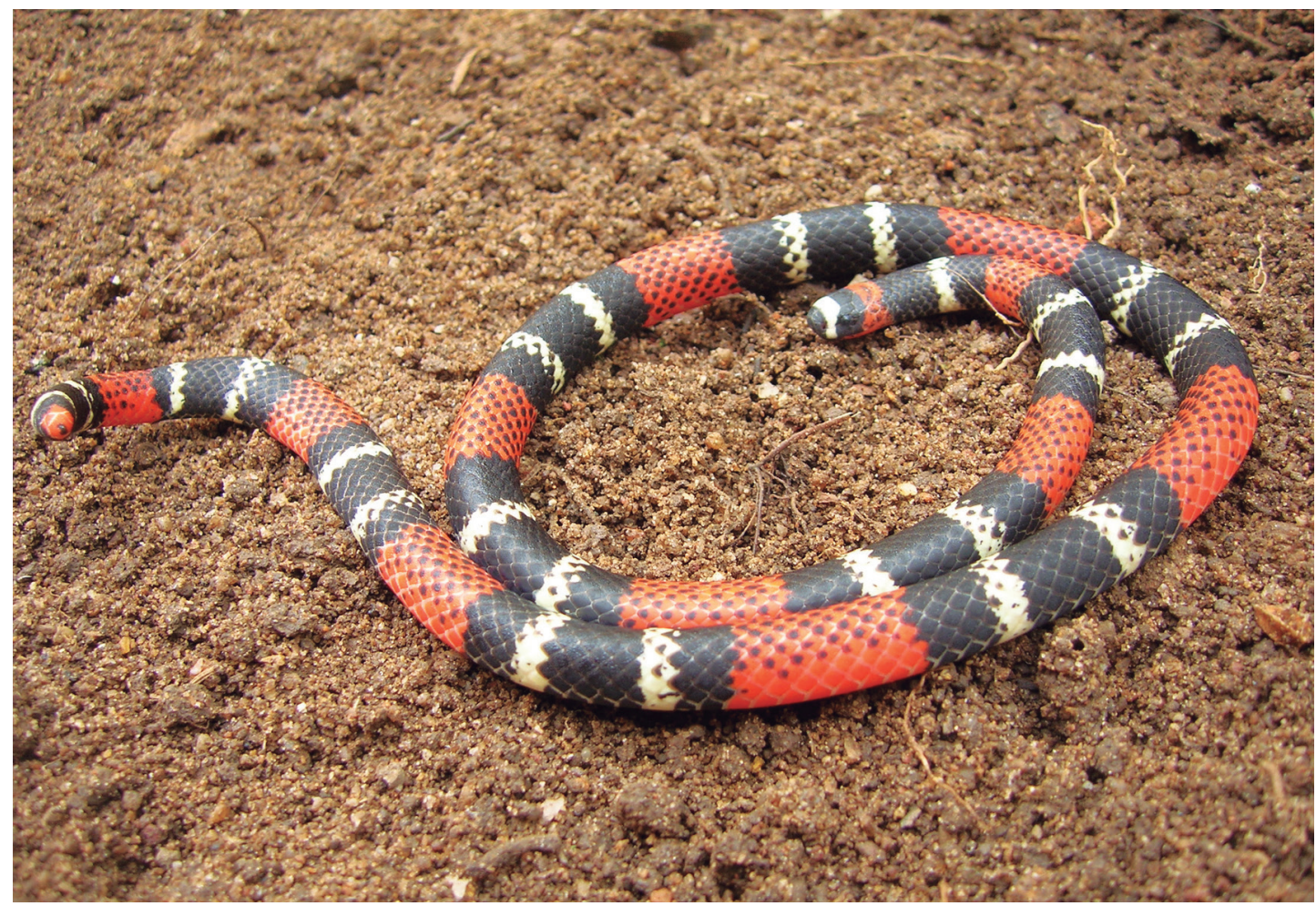

Figure 3. Color pattern of Micrurus decoratus. Live specimen from Venda Nova do Imigrante, Espírito Santo state, currently housed as MNRJ 22742. 
oculars $1+2 / 1+2$; temporals $0+1 / 0+1$; ventrals 190; divided cloacal plate, and subcaudals 19/19 (complete tail).

Two records are here considered doubtful, due to the lack of information and/or precision of collecting sites and also for not having been collected again in those areas: Bahia and Rio Grande do Sul.

The specimen MNRJ 5392 (examined by us and confirmed Micrurus decoratus) was originally part of the Adolpho Lutz Collection, which is currently housed at the MNRJ. The label indicates it was collected in Bahia, housed as “Elaps ?martii?" by Dr. N. Davis in 1930. No precise locality or other information is given about this specimen in the label or in the record book. Although this is an old specimen, it has never been considered in any other study about Micrurus decoratus. The other specimen, MCN 2769 (confirmed M. decoratus, is largely quoted in literature and was examined by several other authors, see discussion) was originally regarded as originating from the municipality of São Leopoldo, state of Rio Grande do Sul, by Lema and Azevedo (1969).

\section{Discussion}

Our results show that $M$. decoratus has a narrower geographical range than previously believed, although we expanded the range northeastward into the state of Espírito Santo with two new records.

\section{Geographic Distribution}

Micrurus decoratus is found in Brazil in the states of Santa Catarina (SC), Paraná (PR), São Paulo (SP), Minas Gerais (MG), Rio de Janeiro (RJ), and Espírito Santo (ES) (Figure 1).

This may not be an abundant species (only 184 records in Brazilian herpetological collections), which is reflected by the few studies that have focused on this species. Consequently, its biology remains poorly known, as stated by Marques (2002) and Campbell and Lamar (1989, 2004).
Terribile et al. (2007) pointed out that the geographic range of this species was more restricted than that proposed by Campbell and Lamar (2004). They also pointed out that the largest geographical range for this species was suggested by Amaral (1929), who included northeastern and central Brazil in the distribution of the species, although at that time up to now, voucher specimens for these areas did not exist.

The results of Terribile et al. (2007) confirmed the occurrence of Micrurus decoratus in the states of São Paulo, Rio de Janeiro and Minas Gerais, but they also predicted its occurrence in northern Paraná, southeastern Santa Catarina, and Espírito Santo, corroborating Amaral (1929), but still with no voucher specimens for the area.

For the state of São Paulo, we reviewed two records of Micrurus decoratus reported from lowland areas: (1) the city of Bertioga (SP) is not the origin of the specimen IBSP 42331. The city is located at sea level, but this individual actually comes from the mountainous area of BiritibaMirim (SP), a neighboring municipality situated in an area of high plateau and mountains. The specimen was originally recorded as coming from the "axis Itatinga-Itapanhaú", which refers to two rivers that rise in Biritiba-Mirim, but are exploited in Bertioga for hydroelectric purposes. This specimen was probably collected by the hydroelectric staff (although there is no record of the supplier) and was misreported as being from "Bertioga" (Terribile et al. 2007). (2) This refers to the toponym "Boracéia", origin of the specimen MZUSP 4830. It is not the city (municipality) of Boracéia, located in the central area of the state of São Paulo, at Tietê river (in a transitional environment between closed and seasonal forest with influence of savannas) (Terribile et al. 2007). Boracéia actually refers to the former Quina experimental station, today Estação Biológica de Boracéia $\left(23^{\circ} 39^{\prime} 00^{\prime \prime} \mathrm{S}, 45^{\circ} 53^{\prime} 00^{\prime \prime} \mathrm{W}, 850\right.$ a.s.l.), in the municipality of Salesópolis, state of São Paulo (high in the mountains of Serra do Mar) (Travassos-Filho and Camargo 1958).

These misreportings certainly influenced the ecological modeling results of Terribile et al. 
(2007). Interestingly, they correctly reported another specimen, IBSP 25219, as being from Boracéia Biological Station, even though they cited it as the "Ecological [sic] Station of Boracéia."

Correction of these two records (Bertioga and Boracéia) allows a more precise interpretation of the chorological design and ecological affinities of Micrurus decoratus.

\section{Atlantic Rainforest Endemism and Altitude Distribution}

Micrurus decoratus is an endemic species to the Atlantic rainforest domain, particularly restricted to elevated locations (from 400 up to 1,600 $\mathrm{m}$ a.s.l) (Figure 1). Its distribution coincides with plateau and mountainous areas occupied by evergreen or seasonal rainforests (RADAMBRASIL 1983, IBGE 2004), which agrees with Marques (2002), Melgarejo (2003), and Marques et al. (2004), but disagrees with Campbell and Lamar $(1989,2004)$ and Terribile et al. (2007), who include lowland forests among the areas occupied by the species.

The occurrence of Micrurus decoratus was previously reported as restricted to places over $700 \mathrm{~m}$ a.s.l. (Marques 2002) and later it was restricted to a range between 457 and 1,643 m a.s.l. (Terribile et al. 2007).

Our results show that $74 \%$ of the locations examined are located above $700 \mathrm{~m}$, and $26 \%$ below it. A careful evaluation of these $26 \%$ showed that all $(N=23$, including those taken from the literature) are from IBSP, MNRJ and MZUSP collections, coming from records provided by third parties. None have accurate collection data and the majority (21/23) have their origin only from municipal centers or names of railway stations - although all of them are located near the mountains of Paranapiacaba (1/23), Bocaina (5/23), Mantiqueira (16/23), and Órgãos (1/23). This reinforces the hypothesis that Micrurus decoratus is found in plateaus and mountains (Prado 1945, Amaral 1977, Marques 2002, Melgarejo 2003, Marques et al. 2004), but not at sea level (Lema and Azevedo 1969, Campbell and Lamar 1989, 2004, Terribile et al. 2007). Although the southernmost record of Micrurus decoratus presented here is at sea level (due to the lack of precise toponym), it is important to mention that the municipality of Joinville also presents areas with elevation above $1,000 \mathrm{~m}$ a.s.l., where this species can probably occur.

\section{First Records for Espírito Santo State}

Previous authors have predicted the occurrence of Micrurus decoratus in the state of Espírito Santo (Amaral 1929, Terribile et al. 2007). Herein we document the first two voucher specimens that confirm the presence of Micrurus decoratus in this state (MBML 2010 and MNRJ 22742).

The Brunoro farm (Venda Nova do Imigrante, ES) has a total area of 60.04 hectares and is largely occupied by a planting of coffee (Coffea arabica) exportation type. The area has steep slopes, and the elevations within the property range from $740-985 \mathrm{~m}$. This farm counts on three fragments of Atlantic Rainforest in the secondary stage of regeneration, and these are located in areas of higher elevation. Although the specimen was collected in one of these fragments, farm workers claim to have captured Micrurus decoratus within the coffee plantation.

The collecting locality in the municipality of Alfredo Chaves, ES, is called Serra da Maravilha, and is characterized by having numerous waterfalls and streams along its entire length. The collection point presents banana (Musa paradisiaca) and coffee (Coffea arabica) plantations, and the legal reserves of the property are located on the tops of the land and at the banks of streams. The Atlantic forest environment of this area is at secondary stage of regeneration, and presents little recent human intervention.

For the new localities at Espírito Santo, the record from Venda Nova do Imigrante constitutes the northernmost locality of Micrurus decoratus distribution, extending its known distribution to 
ca. $300 \mathrm{~km}$ northwest from Caxambu, Minas Gerais, the former northernmost locality (Lutz and Mello 1923).

\section{Doubtful Records}

Two specimens (MCN 2769 and MNRJ 5392) were not considered in our analyses, because of the lack precision and/or information about their origin sites. The specimen MCN 2769 was believed to be collected in São Leopoldo, Rio Grande do Sul State, southern Brazil 2946'12.001" S, 51 09'5.4931" W, 26 m a.s.1.) (Lema and Azevedo 1969). Several authors have cited Micrurus decoratus from Rio Grande do Sul and/or even Santa Catarina, without citing any localities or vouchers (Roze 1967, Peters and Orejas-Miranda 1970, Hoge and Romano 1972, Hoge and Romano-Hoge 1981, Lema et al. 1980, 1984, Campbell and Lamar 1989, 2004, Lema 1994, Marques et al. 2001, 2004, Marques 2002, Melgarejo 2003).

Here we presented the voucher specimen for Joinville (SC), confirming this record. In the other hand, São Leopoldo was latter considered a locality "in error" by Lema himself and other authors (Lema 2002, Di-Bernardo et al 2003, DiBernardo et al. 2004, Terribile et al. 2007), because Micrurus decoratus was never collected again in the region, although many collections have been made in the area. Thus, no accurate toponym was attributed to this specimen, so its origin remains uncertain.

However, although Micrurus decoratus is no longer considered a component of the fauna from Rio Grande do Sul, it is still being cited as part of it by some recent authors (e.g., Abegg and Entiauspe-Neto 2012).

In the present study, no voucher specimens from the state of Rio Grande do Sul was found at the visited collections or records.

The specimen MNRJ 5392 from Bahia, although old (1930), was never cited in any of the publications concerning Micrurus decoratus, perhaps because it was formerly labeled as "Elaps ?martii?" [= Hydrops martii (Wagler,
1824)], another species that has never been reported from Bahia). We found this specimen at the Adolpho Lutz collection (AL), corrected its identification and housed it at the MNRJ herpetological collection. According to the poor available data in Adolfo Lutz's records, he had not been collecting at Bahia in the 1930's (or earlier). There is a tag attached to the specimen where it reads "Dc. N. Davis", so we suppose it was probably donated to AL collection by Nelson C. Davis, a physician that headed the Laboratory of yellow fever in Bahia during part of the early $20^{\text {th }}$ century. Despite our research on these two scientists, in an attempt to discover where the specimen could have been collected, nothing further was found, so its origin remains questionable.

The presence of Micrurus decoratus in Bahia, as well as in Rio Grande do Sul, is plausible, because these states neighbor the current distribution limits and might have similar habitats where this species could be found. Coral snakes have secretive habits and are hard to find, so further field studies should be made in order to investigate the occurrence of this species in these states.

Despite being famous because of their strong venom and bright combination of colors, snakes of the genus Micrurus are still largely unknown in many aspects of their biology. The results presented here not only provide new data and correct old misunderstandings about the distribution of this rare species, but also help to better understand aspects of the real distribution of Micrurus decoratus, pointing out an endemic pattern to the Atlantic Rainforest, restricted to elevated areas and also expanding the limits of the species distribution.

\section{Acknowledgments}

For loaning and/or permitting specimens analyses we are grateful to: Alexandre $\mathrm{O}$. Barreiros, Alexandre de A. Hudson and Bernadete M. de Sousa (UFJF), Daniel Fernandes (ZUFRJ), Francisco L. Franco (IBSP), Hussam 
Zaher (MZUSP), Julio C. de Moura-Leite (MHNCI), Ronaldo Fernandes and Paulo Passos (MNRJ) and Paulo R. Manzani (ZUEC), Gustavo M. Prado, Hélio de Queiroz B. Fernandes, Luísa Soares, Margareth Cancian Roldi and Ronaldo Pinheiro (MBML). Special thanks to Dr. Heinz Grillitsch (NHMW) for sending the photograph of the specimen held at NHMW. We also thank Rodrigo dos Santos (MNRJ) for lab support, to Ulisses Caramaschi (MNRJ), Bryan Jennings (MNRJ), Guilherme Muricy (MNRJ) and Barbara Feital (MNRJ) for the valuable suggestions on the manuscript. RCG and TSS thank Conselho Nacional de Desenvolvimento Científico e Tecnológico (CNPq) for financial support (CNPq grants: 130990/2012-4 and 140640/2011-8).

\section{References}

Abbeg, A. D. and O. M. Entiauspe-Neto. 2012. Serpentes do Rio Grande do Sul. LEW. Tapera. 148 pp.

Amaral, A. 1921 [dated 1922]. Contribuição para o conhecimento dos ofídios do Brasil - A. Parte I - Quatro novas espécies de serpentes brasileiras. III. Elaps fischeri sp. n. Anexos das Memórias do Instituto Butantan 1: $15-17$.

Amaral, A. 1929 [dated 1930]. Estudos sobre ophidios neotrópicos. XVIII. Lista remissiva dos ophidios da região neotrópica. Memórias do Instituto Butantan 4: 129-271.

Amaral, A. 1977. Serpentes do Brasil. Iconografia colorida. Melhoramentos/EDUSP. São Paulo. 248 pp.

Bérnils, R.S. and H. C. Costa (orgs.). 2013. Brazilian reptiles - List of species. Acessible at http://www.sbherpetologia. org.br/. Sociedade Brasileira de Herpetologia. Captured on 4 April 2014.

Campbell, J. A. and W. W. Lamar. 1989. The Venomous Reptiles of Latin America. Cornell University Press. Ithaca. $440 \mathrm{pp}$.

Campbell, J. A. and W. W. Lamar. 2004. The Venomous Reptiles of the Western Hemisphere. Vol. 1. Comstock Publishing/Cornell University Press. Ithaca. 870 pp.

Di-Bernardo, M., M. Borges-Martins, and R.B. Oliveira. 2003. Répteis. Pp. 165-188 in C. S. Fontana, G. A. Bencke, and R. E. Reis (orgs.), Livro Vermelho da Fauna Ameaçada de Extinção no Rio Grande do Sul. $1^{\mathrm{a}}$ Ed. EDIPUCRS. Porto Alegre.
Di-Bernardo, M., M. Borges-Martins, and R. B. Oliveira. 2004. Proposed deletion of eight species of snakes from the Brazilian State of Rio Grande do Sul Herpetofauna. Comunicações do Museu de Ciências e Tecnologia da PUCRS, Série Zoológica 17: 45-50.

Ferreira, R. B. and T. Silva-Soares. 2012. Road mortality of snakes at the Parque Estadual da Fonte Grande, an urban Forest of Southeastern Brazil. Boletim do Museu de Biologia Prof. Mello Leitão, Nova série 29: 5-15.

Giesbrecht, R. M. (ed.) 2014. Estações ferroviárias do Brasil. Electronic database accessible at: http://www.estacoes ferroviarias.com.br. Captured on 10 June 2014.

Google. 2013. Google Earth (7.1.1.1888). URL: http://www. google.com.br.

Hartmann, P. A., M. T. Hartmann, and M. Martins. 2009. Ecologia e história natural de uma taxocenose de serpentes no Núcleo Santa Virgínia do Parque Estadual da Serra do Mar, no sudeste do Brasil. Biota Neotropica 9: $173-184$

Hijmans, R. J. 2012. Diva Gis (7.5.0.0). URL: www.diva-gis. org/.

Hoge, A. R. and S. A. Romano. 1972. Sinopse das serpentes peçonhentas do Brasil, Serpentes Elapidae e Viperidae. Memórias do Instituto Butantan 36: 109-208.

Hoge, A.R. and S.A.R.W.L Romano-Hoge. 1981 [dated 1978/1979]. Sinópse das serpentes peçonhentas do Brasil. Memórias do Instituto Butantan 42/43: 373-496.

IBGE (Instituto Brasileiro de Geografia e Estatística). 2004. Mapa de Vegetação do Brasil, 1: 5.000.000. IBGE Diretoria de Geociências, Rio de Janeiro.

IBGE (Instituto Brasileiro de Geografia e Estatística). 2014. Biblioteca. Electronic database accessible at: http:// www.biblioteca.ibge.gov.br/index.htm. Captured on 10 June 2014

Ihering, R. von. 1910. As cobras do Brasil. I Parte. Revista do Museu Paulista 8: 273-379.

Jan, G. 1858. Plan d'une iconographie descriptive des ophidiens et description sommaire de nouvelles espèces des serpents. Revue et Magasin de Zoologie Pure et Appliquée, Paris (2) 10: 438-449, 514-527.

Lema, T. 1994. Lista comentada dos répteis ocorrentes no Rio Grande do Sul, Brasil. Comunicações do Museu de Ciências e Tecnologia da PUCRS, Série Zoologia 7: 41-150.

Lema, T. 2002. Os Répteis do Rio Grande do Sul: atuais e fósseis - biogeografia - ofidismo. EDIPUCRS. Porto Alegre. 
Lema, T. and A. C. P. Azevedo. 1969. Ocorrência de Micrurus decoratus (Jan) no Rio Grande do Sul, Brasil (Serpentes, Elapidae). Iheringia, Série Zoologia 37: 118-117.

Lema, T., M. E. Fabian-Beurmann, M. L. Araújo, M. L. M. Alves, and M. I. Vieira. 1980. Lista de répteis encontrados na região da grande Porto Alegre, Estado do Rio Grande do Sul. Iheringia, Série Zoologia 55: 27-26.

Lema, T., M. I. Vieira, and M. L. Araújo. 1984. Fauna reptiliana do Norte da Grande Porto Alegre, Rio Grande do Sul, Brasil. Revista Brasileira de Zoologia 2: 203 227.

Lutz, A. and O. Mello. 1923. Duas novas espécies de colubrídeos brasileiros. Folha Medica (Rio de Janeiro) 4: $2-3$.

Marques, O. A. V. 2002. Natural history of the coral snake Micrurus decoratus (Elapidae) from the Atlantic Forest in southeast Brazil, with comments on possible mimicry. Amphibia-Reptilia 23: 228-232.

Marques, O. A. V., A. Eterovic, and I. Sazima. 2001. Serpentes da Mata Atlântica - guia ilustrado para a Serra do Mar. Holos Editora. Ribeirão Preto. 184pp.

Marques, O. A. V., A. Eterovic, and I. Sazima. 2004. Snakes of the Brazilian Atlantic Forest: an illustrated field guide for the Serra do Mar range. Holos Editora. Ribeirão Preto. 205 pp.

Melgarejo, A. R. 2003. Serpentes peçonhentas do Brasil. Pp. 42-70 in J. L. C. Cardoso, F. O. S. França, F. H. Wen, C. M. S. Málaque, and V. Haddad Jr. (eds.), Animais Peçonhentos no Brasil. Sarvier. São Paulo.

Peters, J. A.and B. Orejas-Miranda. 1970. Catalogue of the Neotropical Squamata. Part 1. Snakes. United States National Museum Bulletin 297: 1-347.

Prado, A. 1945. Serpentes do Brasil. Biblioteca Agropecuária de Sítios e Fazendas. São Paulo. 134 pp.

RADAMBRASIL. 1983. Levantamento de Recursos Naturais, v. 32. Folhas SF.23/24 - Rio de Janeiro/Vitória: geologia, geomorfologia, pedologia, vegetação, uso potencial da terra. Projeto RADAMBRASIL. Rio de Janeiro.
Rocha, C. F. D. 1998. Composição e organização da comunidade de répteis da área de Mata Atlântica da região de Linhares, Espírito Santo. Anais do VIII Seminário Regional de Ecologia 8: 869-881.

Roze, J. A. 1967. A checklist of the New World venomous Coral Snakes (Elapidae), with descriptions of new forms. American Museum Novitates 2287: 1-60.

Roze, J. A. 1996. Coral Snakes of the Americas: biology, identification, and venoms. Krieger Publishing Company. Malabar. 328pp.

Sabaj-Pérez, M. H. 2013. Standard symbolic codes for institutional resource collections in herpetology and ichthyology: an online reference. Version 4: 28.

Schmidt, K. P. 1936. Preliminary account of coral snakes of South America. Zoological Series of Field Museum of Natural History 20: 189-203.

Scrocchi, G. J. 1992. Análisis preliminar de la osteologia craneal del gênero Micrurus Wagler (Ophidia: Elapidae). Acta Zoológica Lilloana 41: 311-327.

Silva Jr., N. J. and J. W. S. Sites-Jr. 2001. Phylogeny of South American triad coral snakes (Elapidae: Micrurus) based on molecular characters. Herpetologica 51: 1-22.

Silva-Soares, T., R. B. Ferreira, R. O. L. Salles, and C. F. D. Rocha. 2011. Continental, insular and coastal marine reptiles from the municipality of Vitória, state of Espírito Santo, southeastern Brazil. Check List 7: 290-298.

Terribile, L. C., T. C. S. Anacleto, N. J. Silva Jr., and J. A. F. Diniz-Filho. 2007. Potential geographic distribution of the coral snake Micrurus decoratus Jan, 1858 (Serpentes, Elapidae) in the Atlantic Rainforest of Brazil. Arquivos do Museu Nacional 65: 217-223.

Tonini, J. F. R., L. M. Carão, I. S. Pinto, J. L. Gasparini, Y. L. R. Leite, and L. P. Costa. 2010. Non-volant tetrapods from Reserva Biológica de Duas Bocas, State of Espírito Santo, Southeastern Brazil. Biota Neotropica 10: 339351.

Travassos-Filho, 1. and H. F. A. Camargo. 1958. A Estação Biológica de Boracéia. Arquivos de Zoologia, São Paulo 11: $1-21$. 
Appendix I. Material examined organized alphabetically by Brazilian states.

Dubious records: Bahia: MNRJ 5392; Rio Grande do Sul: São Leopoldo: MCN 2769.

Espírito Santo: Alfredo Chaves: Serra da Maravilha: MBML 2010; Venda Nova do Imigrante: Fazenda Brunoro: MNRJ 22742.

Minas Gerais: Caxambu: Lutz and Mello (1923); Fama: IBSP 10293; Itamonte: Parque Nacional de Itatiaia: Terribile et al. (2007); Juiz de Fora: Retiro railway station: Terribile et al. (2007); Passa-Vinte: Carlos Euler railway station: IBSP 10306; Lima Duarte: IBSP 16703; Parque Estadual do Ibitipoca: UFJF 04; Poços de Caldas: IBSP 9564, 9596, 29404, and 31573; Rio Preto: IBSP 6476.

Paraná: Castro: IBSP 12527; Piraquara: Mananciais da Serra: MHNCI 5895; Quatro Barras: Florestal, Contorno Leste: $\mathrm{MHNCl} 12005$.

Rio de Janeiro: Duas Barras: Monerá railway station: IBSP 17333; Itatiaia: IBSP 1233, 17063, 17327-30, and 25982, MNRJ 1006, MZUSP 3540; Homem de Mello railway station: IBSP 1709 and 9545; Parque Nacional de Itatiaia, Monte Serrat: MNRJ 8271-72; Parque Nacional de Itatiaia (location not specified): Terribile et al. (2007); Nova Friburgo: Terribile et al. (2007); Teodoro de Oliveira: MNRJ 17728; 19859; Petrópolis: Campbell and Lamar (2004), Terribile et al. (2007); Serra das Araras: MNRJ 8235; Resende: IBSP 42946, 46660, 46980, 54392, and 69860; Agulhas Negras: IBSP 18721; Rio Claro: Lídice railway station: IBSP 8979; Teresópolis: IBSP 19524-26, MNRJ 663, ZUFRJ 301; Parque Nacional Serra dos Órgãos: IBSP 19535; Vale da Revolta: MNRJ 12446; Valença: RPPN Santuário Ecológico Serra da Concórdia: MNRJ 16496.

Santa Catarina: Joinville: NHMW 28089:3.

São Paulo: Águas da Prata: ZUEC 600; Cascata railway station: IBSP 68; 6330; 6562; Atibaia: IBSP 54533; Bananal: IBSP 9599, 27740-41, 33192, 34164, and 41130; Trutário Acqua S.A.: MNRJ 9328; Biritiba-Mirim: IBSP 54402; Casa Grande: IBSP 23235; Itapanhau: IBSP 42331; Cabreúva: IBSP 49611; Cajamar: IBSP 43745; 60270; Campo Limpo Paulista: IBSP 67, 4754, 5676, 6886, 9416, 9945, and 10017; Cotia: Caucaia do Alto: IBSP 8516; Cruzeiro: Perequê railway station: Terribile et al. (2007); Cunha: IBSP 44647, 46043, 51261, 62665, and 66669; Campos de Cunha: Terribile et al. (2007); Embu-Guaçu: IBSP 56076; Franco da Rocha (Juqueri railway station): IBSP 6923; Ibiúna: IBSP 28142, 33147, 46039, 51356 and 64297; Boava: IBSP 44618; Itapecerica da Serra: IBSP 64300; km 294 of the BR-116 highway: IBSP 45071; Jarinu: IBSP 42693 and 54789; Jundiaí: IBSP 9866, 23233, and 62340; Juquitiba: IBSP 54274; Lorena: IBSP 1455; Mairiporã: IBSP 43005, 50644, 61107, 62328-29, and 64296; Mauá: IBSP 53779, 53886, and 66470; Mogi das Cruzes: IBSP 932, 9555, and 53263; Mogi Mirim: IBSP 62062; Monte Alegre do Sul: IBSP 9597; Paraibuna: IBSP 53077; Piedade: IBSP 12093, 21113, 47637, and 49102; Sarapuí dos Torres: IBSP 42684; Pindamonhangaba: IBSP 1456; Piquete: IBSP 442 and 32098, MZUSP 66; Queluz: IBSP 18263; Ribeirão Pires: IBSP 4841, 9492, 42561, 44500-01, 45190, 54796, and 55667; Rio Grande da Serra: IBSP 25002, 49067, 54779-80, and 62966; Salesópolis: IBSP 26189; Estação Biológica de Boracéia: IBSP 25219, MZUSP 2349-50, 4830, and 4915; Santa Branca: Hartmann et al. (2009); Santo Antônio do Pinhal (Eugênio Lefèvre railway station): IBSP 7027; São Bernardo do Campo: IBSP 72863; São João da Boa Vista: Campbell and Lamar (2004); São José do Barreiro: Terribile et al. (2007); Fazenda do Bonito: IBSP 1849, MZUSP 10575; Funil: MZUSP 68; São Luís do Paraitinga: IBSP 74643-4; Parque Estadual Serra do Mar, Núcleo Santa Virgínia: Hartmann et al. (2009); São Paulo: IBSP 1816, 6884, and 51850; Belém: IBSP 841; Campo Limpo: IBSP 8327; Taipas: IBSP 55700; São Roque: IBSP 15704 and 44187; São João Novo railway station, former São João railway station: IBSP 7102, 7695, 7732, 9573, 9580, 9598, 9863, 10000, and 10003; Ponte Lavrada: IBSP 7717; Suzano: Terribile et al. (2007); Tapiraí: IBSP 68940; Taubaté: IBSP 17565; Tremembé: IBSP 44445; Vargem Grande Paulista: Granja Barra Azul: IBSP 43222. 